\title{
Optimization, Purification, and Characterization of Haloalkaline Serine Protease from a Haloalkaliphilic Archaeon Natrialba hulunbeirensis Strain WNHS14
}

\author{
Rania S Ahmed ${ }^{1}$, Amira M Embaby ${ }^{2}$, Mostafa Hassan ${ }^{3}$, Nadia A Soliman ${ }^{1 *}$, and Yasser R Abdel-Fattah ${ }^{1}$ \\ ${ }^{1}$ Bioprocess Development Department, Genetic Engineering and Biotechnology Research Institute (GEBRI), City for Scientific Research and \\ Technological Applications, Alexandria, Egypt \\ ${ }^{2}$ Institute of Graduate Studies and Research, Biotechnology Department, ${ }^{3}$ Institute of Graduate Studies and Research, Environmental Studies \\ Department, Alexandria University, Alexandria 21526, Egypt
}

Received: April 12, 2019 / Revised: May 30, 2019 / Accepted: July 19, 2019

\begin{abstract}
The present study addresses isolation, optimization, partial purification, and characterization of a haloalkaline serine protease from a newly isolated haloarchaeal strain isolated from Wadi El Natrun in Egypt. We expected that a two-step sequential statistical approach (one variable at a time, followed by response surface methodology) might maximize the production of the haloalkaline serine protease. The enzyme was partially purified using Hiprep 16/60 sephacryl S-100 HR gel filtration column. Molecular identification revealed the newly isolated haloarchaeon to be Natrialba hulunbeirensis strain WNHS14. Among several tested physicochemical determinants, casamino acids, $\mathrm{KCl}$, and $\mathrm{NaCl}$ showed the most significant effects on enzyme production as determined from results of the One-Variable-At-A-time (OVAT) study. The BoxBehnken design localized the optimal levels of the three key determinants; casamino acids, $\mathrm{KCl}$, and $\mathrm{NaCl}$ to be $0.5 \%(\mathrm{w} / \mathrm{v}), 0.02 \%(\mathrm{w} / \mathrm{v})$, and $15 \%(\mathrm{w} / \mathrm{v})$, respectively, obtaining $62.9 \mathrm{U} / \mathrm{ml}$ as the maximal amount of protease produced after treatment at $40^{\circ} \mathrm{C}$, and $\mathrm{pH} 9$ for 9 days with 6 -fold enhancement in yield. The enzyme was partially purified after size exclusion chromatography with specific activity, purification fold, and yield of $1282.63 \mathrm{U} / \mathrm{mg}, 8.9$, and $23 \%$, respectively. The enzyme showed its maximal activity at pH, temperature, and $\mathrm{NaCl}$ concentration optima of $10,75^{\circ} \mathrm{C}$, and $2 \mathrm{M}$, respectively. Phenylmethylsulfonyl fluoride (PMSF, 5 mM) completely inhibited enzyme activity.
\end{abstract}

Keywords: Protease, Haloalkaliphilic, archaea, Natrialba hulunbeirensis, enzyme production

\section{Introduction}

Halophilic proteases are widely exploited in the processing of leather, detergents, and food. Since, halophilic proteases are adapted to extreme environments, they are surprisingly stable and therefore they could be of a great importance for industrial processes that are performed under high values of temperature and ionic strength and in the organic solvents [15]. The domain

\section{*Corresponding author}

Tel: +203 4593413, Fax: +2034593423

E-mail: nadiastuttgart@yahoo.com
Archaea was first suggested by Woese and Fox [44] as one of the three domains of life. Within this domain is a separate cluster for the halophilic archaea which grow optimally in media with high $\mathrm{NaCl}$ (3.5-5.2 M) [34]. In hypersaline environments, extremely halophilic archaea are often the dominant members of the microbial population due to their ability to balance osmotic pressure using a low-energy strategy [30]. Many haloarchaea produce proteolytic enzymes that function at high salt concentrations (3-4 mol $\left.\mathrm{l}^{-1} \mathrm{NaCl}\right)$ at which other proteins usually precipitate [24]. Such unique properties make these enzymes fundamentally and biotechnologically 
important for application. In industrial scale the use of halophilic microorganisms is appreciated where no contamination risk. In this way, a new approach for cultivating halophilic microorganisms, such as open ponds, could be adopted instead of traditional more expensive closed bioreactors [37]. Optimization of medium components can help in increasing the yield of the enzymes, therefore this study focused on enzyme production, optimization, purification and characterization of newly produced haloalkaliphilic protease enzyme by Natrialba hulunbeirensis strain WNHS14 isolated from Wadi El Natrun, El Hamra Lake, Egypt.

\section{Materials and Methods}

\section{Isolation, screening and identification}

The haloalkaliphilic strains used in this study were isolated from soil samples collected from Wadi El Natrun, El Hamra Lake, Egypt. Sediment and water samples were collected during winter from El Hamra Lake (pH 10), Wadi El Natrun in Egypt, where the temperature was about $20^{\circ} \mathrm{C}$. For the enrichment of haloalkaliphilic archaea, media were supplemented with $1 \mathrm{ml}$ water sample or $1 \mathrm{~g}$ sediment sample. Samples were cultivated into $250 \mathrm{ml}$ Erlenmeyer flask containing $50 \mathrm{ml}$ of the medium, where six different media ( $\mathrm{pH} 10$ ) were tested (M1-M6) [8, 9, 12, 16, 17, 45], respectively, then kept under shaking condition $(200 \mathrm{rpm})$ at 37 and $45^{\circ} \mathrm{C}$ for 14 days. Subsequent dilutions of 14-days-old culture were placed out into the same medium for further purification. The purified isolate was maintained on agar plate of the same medium, subcultured at regular intervals of 1 month and stored at $4{ }^{\circ} \mathrm{C}$. All isolates were screened for production of haloalkaliphilic protease each under growth preferred medium, temperature and $\mathrm{pH}$ (10). WNHS14 was selected as the most potent strain under growth conditions: temperature $\left(45^{\circ} \mathrm{C}\right), \mathrm{pH}(10)$, salinity (15\%) using M2 medium after 9-days. Subsequently, the selected isolate (WNHS14) was characterized morphologically, microscopically (scanning electron microscope (SEM)) and identified by $16 \mathrm{~S}$ rRNA gene sequencing using specific archael forward 16S primer (5'-ATTCCGGTTGATCCTGCCGG-3') and reverse 16S primer (5'-TACGGYACCTTGTTACGACTT-3'). The 16S rRNA sequence was aligned with the deposited 16S rRNA sequences deposited in the international nucleotide sequence database collabortaion (INSDC) to assess its similarity through BLASTn search (http:// blast.ncbi.nlm.nih.gov/Blast.cgi), subsequently, the sequence was deposited at GenBank under the accession number KP765047.1.

\section{Enzyme assay}

Protease activity was measured by the method of Kembhavi et al. [20] using casein as a substrate and cellfree supernatant as a source of enzyme under reaction conditions using glycine $-\mathrm{NaOH}$ plus $2.5 \mathrm{M} \mathrm{NaCl}$ buffer, $\mathrm{pH} 9$ at $45^{\circ} \mathrm{C}$ for $10 \mathrm{~min}$. One unit of protease activity was defined as the amount of enzyme required to liberate $1 \mu \mathrm{g}$ of tyrosine per min under the experimental conditions. A standard curve with tyrosine was established.

\section{Enzyme production}

Pre-culture preparation. A starting culture of Natrialba hulunbeirensis WNHS14 was grown in $250 \mathrm{ml}$ Erlenmeyer flask containing $50 \mathrm{ml}$ of the medium as described by Xu et al. [45] which has the following composition in $\mathrm{g} / \mathrm{l}$ : casamino acids, 7.5 ; yeast extract, 10; trisodium citrate, $3 ; \mathrm{MgSO}_{4} \cdot 7 \mathrm{H}_{2} \mathrm{O}, 0.3 ; \mathrm{KCl}, 2 ; \mathrm{FeSO}_{4}$. $7 \mathrm{H}_{2} \mathrm{O}, 2 \times 10^{-5} ; \mathrm{MnCl}_{2} \cdot 4 \mathrm{H}_{2} \mathrm{O}, 3.6 \times 10^{-4} ; \mathrm{NaCl}, 200$; $\mathrm{Na}_{2} \mathrm{CO}_{3}$, 8.0. The preculture cells were grown under conditions $\left(45^{\circ} \mathrm{C}\right),(200 \mathrm{rpm})$ till reach $\mathrm{OD}_{\lambda 600}(\sim 0.6)$. Then this culture was used for inoculating the production media using $2 \%$ inoculum size.

OVAT-approach. Stepwise OVAT approach was applied initially to determine the effect of different nitrogen sources, carbon sources, temperature(s) and $\mathrm{pH}(\mathrm{s})$ on the production of protease using the above mentioned medium as a basal medium at fixed time (9 days) and shaking (200 rpm).

\section{Effect of carbon and nitrogen sources on protease pro- duction}

Effect of different carbon and nitrogen sources on protease production was carried out by replacing yeast extract $(10 \mathrm{~g} / \mathrm{l})$ and casamino acids $(7.5 \mathrm{~g} / \mathrm{l})$ in the basal medium with a sole nitrogen source (5 g/l) either organic (peptone, yeast extract, casamino acids, skimmed milk, soybean flour and malt extract) or inorganic $\left(\mathrm{NH}_{4}\right)_{2} \mathrm{SO}_{4}$, $\mathrm{NH}_{4} \mathrm{Cl}$, urea and $\mathrm{NaNO}_{3}$. Subsequently, the effect of different carbon sources was estimated through replacing 
trisodium citrate $(3 \mathrm{~g} / \mathrm{l})$ by other various carbon sources (5 g/l) and keeping the nitrogen source (casamino acids at conc. $5 \mathrm{~g} / \mathrm{l}$ ). Sugars such as xylose, glucose, fructose, sucrose, maltose and lactose were used. Furthermore, other carbon sources such as starch, mannitol and sodium acetate were tested as well.

\section{Effect of temperature and $\mathrm{pH}$ on protease production.}

Temperature was tested by incubating the cultures in a range of temperature $\left(30-50^{\circ} \mathrm{C}\right)$ with increments of $5{ }^{\circ} \mathrm{C}$. In order to test the effect of $\mathrm{pH}$ on protease production, the optimum medium was adjusted at different pHs (7.0-10.5 with increment 0.5). Cultural conditions were set at optimum temperature for 9 days with shaking.

\section{Response surface methodology (Box-Behnken Design)}

The next step of the optimization was to determine the optimum levels of significant variables screened by OVAT approach. For this purpose, response surface methodology using Box-Behnken design was adopted.

\begin{tabular}{|c|c|c|c|c|c|}
\hline \multirow{2}{*}{ Trial } & \multirow{2}{*}{$\begin{array}{c}\text { Cas.acids }{ }^{*} \\
\left(\mathrm{X}_{1}\right)\end{array}$} & \multirow{2}{*}{$\begin{array}{l}\mathrm{KCl} \\
\left(\mathrm{X}_{2}\right)\end{array}$} & \multirow{2}{*}{$\begin{array}{c}\mathrm{NaCl} \\
\left(\mathrm{X}_{3}\right)\end{array}$} & \multicolumn{2}{|c|}{ Protease activity (U/ml) } \\
\hline & & & & Experimental & Predicted \\
\hline 1 & $-1(0.5)$ & $-1(0.02)$ & $0(20)$ & 45.60 & 39.78125 \\
\hline 2 & $1(1)$ & $-1(0.02)$ & $0(20)$ & 17.60 & 21.43125 \\
\hline 3 & $-1(0.5)$ & $1(0.2)$ & $0(20)$ & 41.60 & 37.76875 \\
\hline 4 & $1(1)$ & $1(0.2)$ & $0(20)$ & 16.00 & 21.81875 \\
\hline 5 & $-1(0.5)$ & $0(0.11)$ & $-1(15)$ & 47.20 & 55.34375 \\
\hline 6 & $1(1)$ & $0(0.11)$ & $-1(15)$ & 45.60 & 44.09375 \\
\hline 7 & $-1(0.5)$ & $0(0.11)$ & $1(25)$ & 15.60 & 17.10625 \\
\hline 8 & $1(1)$ & $0(0.11)$ & $1(25)$ & 2.200 & -5.94375 \\
\hline 9 & $0(0.75)$ & $-1(0.02)$ & $-1(15)$ & 54.00 & 51.67500 \\
\hline 10 & $0(0.75)$ & $1(0.2)$ & $-1(15)$ & 56.95 & 52.637500 \\
\hline 11 & $0(0.75)$ & $-1(0.02)$ & $1(25)$ & 5.000 & 9.312500 \\
\hline 12 & $0(0.75)$ & $1(0.2)$ & $1(25)$ & 4.400 & 6.725000 \\
\hline 13 & $0(0.75)$ & $0(0.11)$ & $0(20)$ & 18.00 & 17.76000 \\
\hline 14 & $0(0.75)$ & $0(0.11)$ & $0(20)$ & 17.50 & 17.76000 \\
\hline 15 & $0(0.75)$ & $0(0.11)$ & $0(20)$ & 17.78 & 17.76000 \\
\hline
\end{tabular}

${ }^{*}$ Casamino acids.

Levels of independent variables presented between brackets are expressed in terms of $(\mathrm{w} / \mathrm{v}) \%$.
This optimization process involves three main steps: performing the statistically designed experiment, estimating the coefficients of the structured mathematical model and predicting the response and checking the adequacy of the model. Table 1 presents the design matrix with both coded and real values [expressed in (w/v)\%] of the studied variables along with the trial response. Each variable was studied on three levels, coded $-1,0$, and +1 for low, middle, and high concentrations, respectively. The combinations were performed and the haloalkaline protease activity was calculated for each trial after 9 days incubation. The results were fitted to the following second-order polynomial structured model for three variables:

$$
\begin{aligned}
\mathrm{Y}= & \beta_{0}+\beta_{1}\left(\mathrm{X}_{1}\right)+\beta_{2}\left(\mathrm{X}_{2}\right)+\beta_{3}\left(\mathrm{X}_{3}\right)+\beta_{12}\left(\mathrm{X}_{1} \mathrm{X}_{2}\right)+\beta_{13}\left(\mathrm{X}_{1} \mathrm{X}_{3}\right) \\
& +\beta_{23}\left(\mathrm{X}_{2} \mathrm{X}_{3}\right)+\beta_{11}\left(\mathrm{X}_{1}\right)^{2}+\beta_{22}\left(\mathrm{X}_{2}\right)^{2}+\beta_{33}\left(\mathrm{X}_{3}\right)^{2}
\end{aligned}
$$

where, $\mathrm{Y}$ is the predicted response (haloalkaline protease activity), $\beta_{0}$ is constant, $\beta_{1}, \beta_{2}$ and $\beta_{3}$ are linear coefficients, $\beta_{12}, \beta_{13}$ and $\beta_{23}$ are cross product coefficients, and $\beta_{11}, \beta_{22}$ and $\beta_{33}$ are quadratic coefficients. The maximal predicted response of variables and coefficients were calculated using Microsoft Excel 2007.

\section{Statistical analysis of data}

Multiple non-linear regression was carried out for the enzyme activity data using Microsoft Excel 2007 to estimate the t-values, $p$-values, and confidence levels expressing the $p$-value as a percentage. The quality of fit of the second-order polynomial model equation was expressed via the multiple correlation coefficients $R$ and determination coefficient $R^{2}$. The relationship between the responses and the experimental levels of each of the variables was visualized using three-dimensional graphs generated by STATISTICA 5.0 software. The optimal enzyme activity value was estimated using the Solver function of the Microsoft Excel tools. To determine the validity of the quadratic polynomial model, a verification experiment was carried out under the predicted optimal conditions, while monitoring the haloalkaline protease activity.

Growth curve and protease production. Incubation of Natrialba hulunbeirensis WNHS14 was carried out under initial and optimized conditions while monitoring 
the growth and haloalkaline protease production.

Purification of the Haloalkaline protease. The cell-free culture supernatant was concentrated by ultrafiltration (Amicon ultra-50 centrifugal filter device, Merck KGaA, Germany) with $10 \mathrm{kDa}$ membrane filter. The concentrated enzyme was applied onto the Hiprep 16/60 sephacryl S-100 HR gel filtration column equilibrated with $100 \mathrm{mM}$ glycine-NaOH buffer, $\mathrm{pH} 9$ containing $2 \mathrm{M}$ $\mathrm{NaCl}$. Fractions were collected at a flow rate of $0.7 \mathrm{ml} /$ min and analyzed for protein content and proteolytic activity. Fractions containing high proteolytic activity were pooled together. The pooled fractions were then concentrated and desalted against $100 \mathrm{mM}$ glycine$\mathrm{NaOH}$ buffer, pH 9 using Amicon ultra-50 centrifugal filter device (membrane cut off of $10 \mathrm{kDa}$ ).

Protein methods. Protein concentration was determined by the method of Lowry et al. [25]. A standard curve with BSA was established. SDS-PAGE [23] was performed to monitor the purification steps. Protein gels were stained with silver staining according to the method of Mortz et al. [28].

\section{Enzyme characterization}

Effect of temperature. The optimum temperature for the partially purified protease was determined by assaying enzyme activity under various temperatures (40$85^{\circ} \mathrm{C}$ ) in $2.5 \mathrm{M} \mathrm{NaCl} / 100 \mathrm{mM}$ glycine- $\mathrm{NaOH}$ buffer $\mathrm{pH} 9$, using casein substrate (1\%). In order to monitor the thermal stability, samples of the partially purified enzyme were pre-incubated at different temperatures $\left(55-75^{\circ} \mathrm{C}\right)$. Aliquots were then taken at different time intervals, and the remaining activity was then measured.

Effect of pH. Relative protease activity was determined using buffers $(100 \mathrm{mM})$ of varying $\mathrm{pH}$, viz. phosphatecitrate ( $\mathrm{pH} 5.8$ ), phosphate ( $\mathrm{pH} 5.8-8)$, tris-HCl ( $\mathrm{pH} 7.8-$ 9), glycine- $\mathrm{NaOH}$ ( $\mathrm{pH} 9-10)$, carbonate-bicarbonate $(\mathrm{pH}$ 9.2-10.4), bicarbonate- $\mathrm{NaOH}$ (pH 10-11), phosphate$\mathrm{NaOH}(\mathrm{pH} 11-12)$ and $\mathrm{KCl}-\mathrm{NaOH}(\mathrm{pH} 12,12.4)$. All buffers had $\mathrm{NaCl}$ concentration of 2.5 M. To study the pH stability, the enzyme was pre-incubated with the above-mentioned buffers at room temperature for $60 \mathrm{~min}$ and aliquots were taken at different time intervals to measure the residual protease activity.

\section{Effect of $\mathrm{NaCl}$}

To determine optimum salt concentration, the amount of $\mathrm{NaCl}$ in assay mixture was varied from 0.5 to $4.5 \mathrm{M}$. The activity was calculated and expressed in percentage relative activity considering the maximum value as $100 \%$. To measure the activity of $\mathrm{NaCl}$-free protease, the purified enzyme solution was first eluted with $100 \mathrm{mM}$ $\mathrm{Na}_{2} \mathrm{CO}_{3}-\mathrm{NaHCO}_{3}$ buffer ( $\mathrm{pH}$ 10) by ultrafiltration using Amicon ultra-50 centrifugal filter device, with $10 \mathrm{k}$ Da membrane filter. Then, the $\mathrm{NaCl}$-removed protease was subjected to proteolytic activity assay in the absence of $\mathrm{NaCl}$.

Effect of some additives. The effects of some surfactants (Triton X-100, Tween 80) and reducing agent (SDS) on the partially purified protease activity were tested at $0.1,0.5,1 \%$ final concentration. The effects of protease inhibitor (PMSF); chelating agent, (EDTA) and some metals of the salts $\left(\mathrm{CaCl}_{2}, \mathrm{MgSO}_{4}, \mathrm{ZnSO}_{4}, \mathrm{HgCl}_{2}\right.$, $\mathrm{CuSO}_{4}, \mathrm{KCl}, \mathrm{MnCl}_{2}, \mathrm{FeSO}_{4} \& \mathrm{CoCl}_{2}$ ) on protease activity were investigated at 1 and $5 \mathrm{mM}$ final concentration. The enzyme was pre-incubated with each additive in $2 \mathrm{M} \mathrm{NaCl} / 100 \mathrm{mM} \mathrm{Na}_{2} \mathrm{CO}_{3}-\mathrm{NaHCO}_{3}$ buffer for $30 \mathrm{~min}$ at room temperature.

\section{Results and Discussion}

\section{Isolation of Haloalkaliphilic-protease producer isolates from Wadi-El-Natrun and El-Hamra Lake}

Most of the colonies obtained showed different shades of pink, orange and red colors while others had white, beige and colorless colonies. Total of 49 isolates were obtained, out of which 10 were from water (WNHW1WNHW10) and 39 from sediment (WNHS1-WNHS39). Quantitative estimation of the proteolytic activity for the isolates was monitored along 12 days using isolation medium. Most of the isolates did not show any proteolytic activity during the first 3 days. However, they started to produce extracellular protease after 6 days incubation. WNHS14 had the highest proteolytic activity (10 U/ml) among the isolates under investigation, after 9 days incubation therefore, it was selected for further studies.

\section{Phenotypic and genotypic characterization for WNHS14 strain}

The physiological and morphological characteristics of 

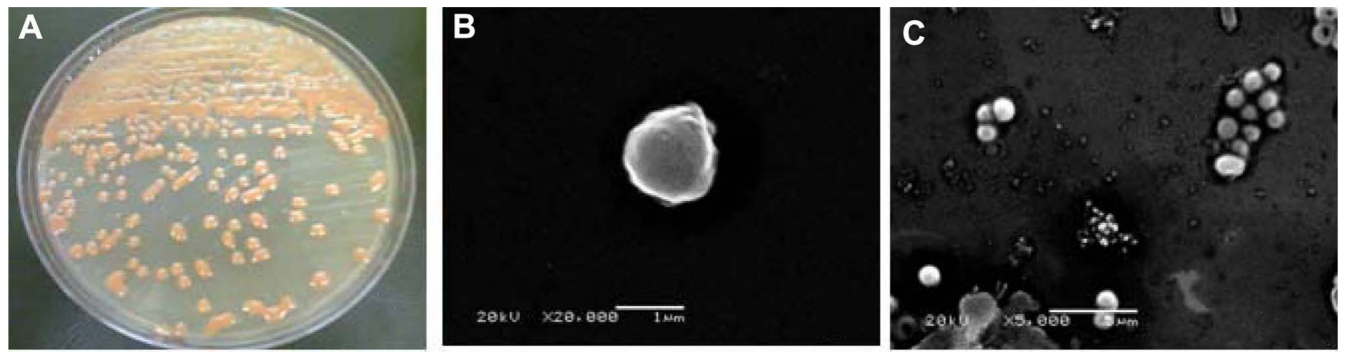

Fig. 1. Morphological characteristics for colony in agar plate (A) and cells micrograph (B \& C) under SEM of the selected isolate (WNHS14).

the isolate WNHS14 showed that it is haloalkaliphilic (pH 10, $\mathrm{NaCl}$ up to $30 \%$ ), Gram- negative, small round orange pigmented colonies, cocci-shaped cells with diameter of $1.3 \mu \mathrm{m}$ as illustrated by the scanning electron micrograph (Fig. 1A-C). To identify this strain, the full length of 16S rRNA gene was amplified, sequenced and deposited at GenBank (Accession no. KP765047.1). Comparison of the obtained sequence with other sequences available at INSDC revealed the WHW14 is a typical Archaea, class Halobacteria and 99\% similar to Natrialba hulunbeirensis.

It was pointed out that members of the class Halobacteria displayed extreme polymorphism, having several morphologic shapes ranging from rods to pleomorphic rods, cocci, pleomorphic, squares and triangles [4]. Colonies of halophilic archaea are various shades of red due to the presence of $\mathrm{C} 50$ carotenoids (bacterioruberins) [21]. Halophiles can be loosely classified as slightly, moderately or extremely halophilic, depending on their requirement of $\mathrm{NaCl}$. Slight halophiles grow optimally at $0.2-0.85 \mathrm{M}(1-5 \%) \mathrm{NaCl}$; moderate halophiles grow optimally at $0.85-3.4 \mathrm{M}(5-20 \%) \mathrm{NaCl}$; and extreme

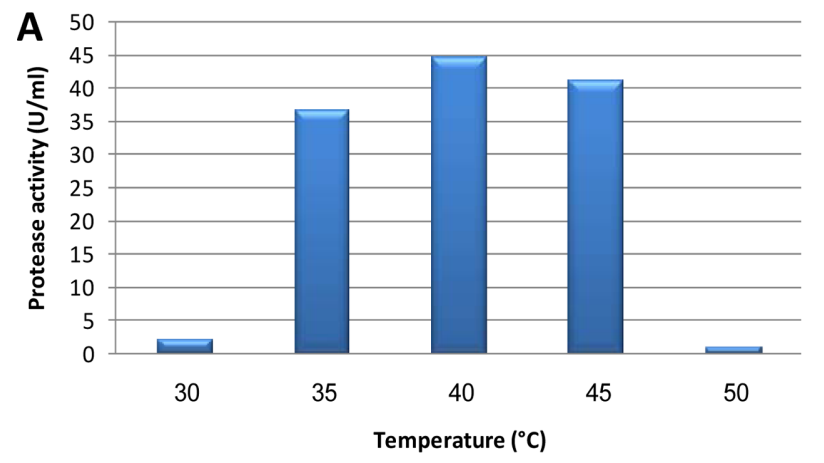

halophiles grow optimally at $3.4-5.1 \mathrm{M}(20-30 \%) \mathrm{NaCl}$ [7]. WNHS14 isolate is considered extreme halophiles, due to its ability to grow optimally at $15-20 \% \mathrm{NaCl}$ with significant growth in presence of $30 \% \mathrm{NaCl}$ and lack of growth below $15 \% \mathrm{NaCl}$.

\section{OVAT approach for enhancing enzyme production}

Haloalkaliphilic archaea provide a valuable resource of proteases which have potential for application to biotechnology. The effect of various nutritional factors on the production of protease in haloalkaliphilic archaea has been poorly investigated. Therefore, the effect of nitrogen, carbon sources, temperature and $\mathrm{pH}$ on the haloalkaliphilic protease production by haloarchaeon WNHS14 were highlighted and analyzed. Data showed that among the organic nitrogen sources used, casamino acids, skimmed milk and yeast extract enhanced the extracellular protease production (36.2, 33.3 and $25.7 \mathrm{U} /$ $\mathrm{ml}$, respectively). The nitrogen sources affecting extracellular protease production by studied strain appear to be somewhat different from those reported for the production of haloalkaliphilic extracellular protease from

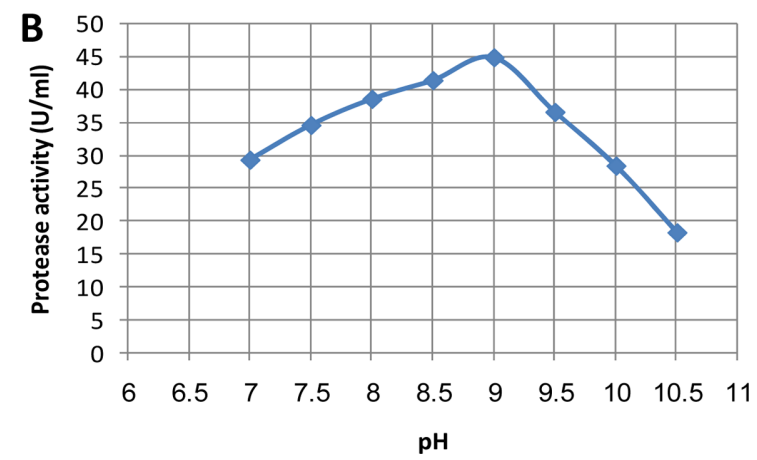

Fig. 2. Effect of incubation temperatures (A) and pHs (B) on haloalkaline protease production by $N$. hulunbeirensis strain WNHS14. 
the haloarchaeon Halogeometricum sp. TSS101 [42] and that secreted by the extremely halophilic archaeon Halobacterium sp. Js1 [43], which were stimulated by soybean flour and peptone. However, they both were inhibited by urea and ammonium chloride and they were activated by skim milk [42, 43]. On the other hand the added carbon sources did not improve the extracellular protease production by WNHS14, and the maximum (36.79 U/ml) was obtained in absence of any carbon source. Similarly, the presence of glucose had no significant effect on the production of $\mathrm{CP} 1$ protease from the moderately halophilic bacterium Pseudoalteromonas sp. strain CP76 [36]. Besides, glucose and starch couldn't be utilized by Halobacterium sp. Js1 [43], while the proteolytic production by Haloferax lucentensis VKMM 007 increased significantly upon using soluble starch as a carbon source [27]. Additionally, N. hulunbeirensis strain WNHS14 showed gradual increase in the protease production with increasing temperature and $\mathrm{pH}$ (Fig. $2 \mathrm{~A}, \mathrm{~B})$, respectively and the optima at $40^{\circ} \mathrm{C}$ and 9 $(44.9 \mathrm{U} / \mathrm{ml})$. For extracellular enzymes, temperature was found to influence their secretion, possibly by changing the physical properties of the cell membrane [35]. Haloalkaliphilic microorganisms require not only high salt but also alkaline $\mathrm{pH}$ for growth and enzyme secretion. The optimum $\mathrm{pH}$ range between 9 and 10 for protease production is common among alkaliphilic and haloalkaliphilic organisms [1,32].

\section{Response surface methodology (Box-Behnken Design)}

Based on OVAT test, casamino acids $\left(\mathrm{X}_{1}\right), \mathrm{KCl}\left(\mathrm{X}_{2}\right)$ and $\mathrm{NaCl}\left(\mathrm{X}_{3}\right)$ showed significant effect on protease production. Thus, they were further studied at three levels: $-1,0$ and +1 to determine the optimum response region for haloalkaline protease activity.

Presenting the experimental results in the form of surface plots, Fig. 3 shows that lower casamino acids, $\mathrm{KCl}$, and $\mathrm{NaCl}$ concentrations supported a high protease activity level. To predict the optimal point, a second order polynomial function was fitted to the experimental results (nonlinear optimization algorithm) of protease activity:

$$
\begin{aligned}
\mathrm{Y}= & 17.76-8.575 \mathrm{X}_{1}-0.406 \mathrm{X}_{2}-22.069 \mathrm{X}_{3}+0.6 \mathrm{X}_{1} \mathrm{X}_{2} \\
& -2.95 \mathrm{X}_{1} \mathrm{X}_{3}-0.888 \mathrm{X}_{2} \mathrm{X}_{3}+5.001 \mathrm{X}_{1}^{2}+7.439 \mathrm{X}_{2}^{2} \\
& +4.889 \mathrm{X}_{3}^{2}
\end{aligned}
$$

where $\mathrm{X}_{1}, \mathrm{X}_{2}$ and $\mathrm{X}_{3}$ are casamino acids, $\mathrm{KCl}$ and $\mathrm{NaCl}$ respectively. At the model level, the correlation measures used to estimate the regression equation are the multiple correlation coefficients $R$ and determination
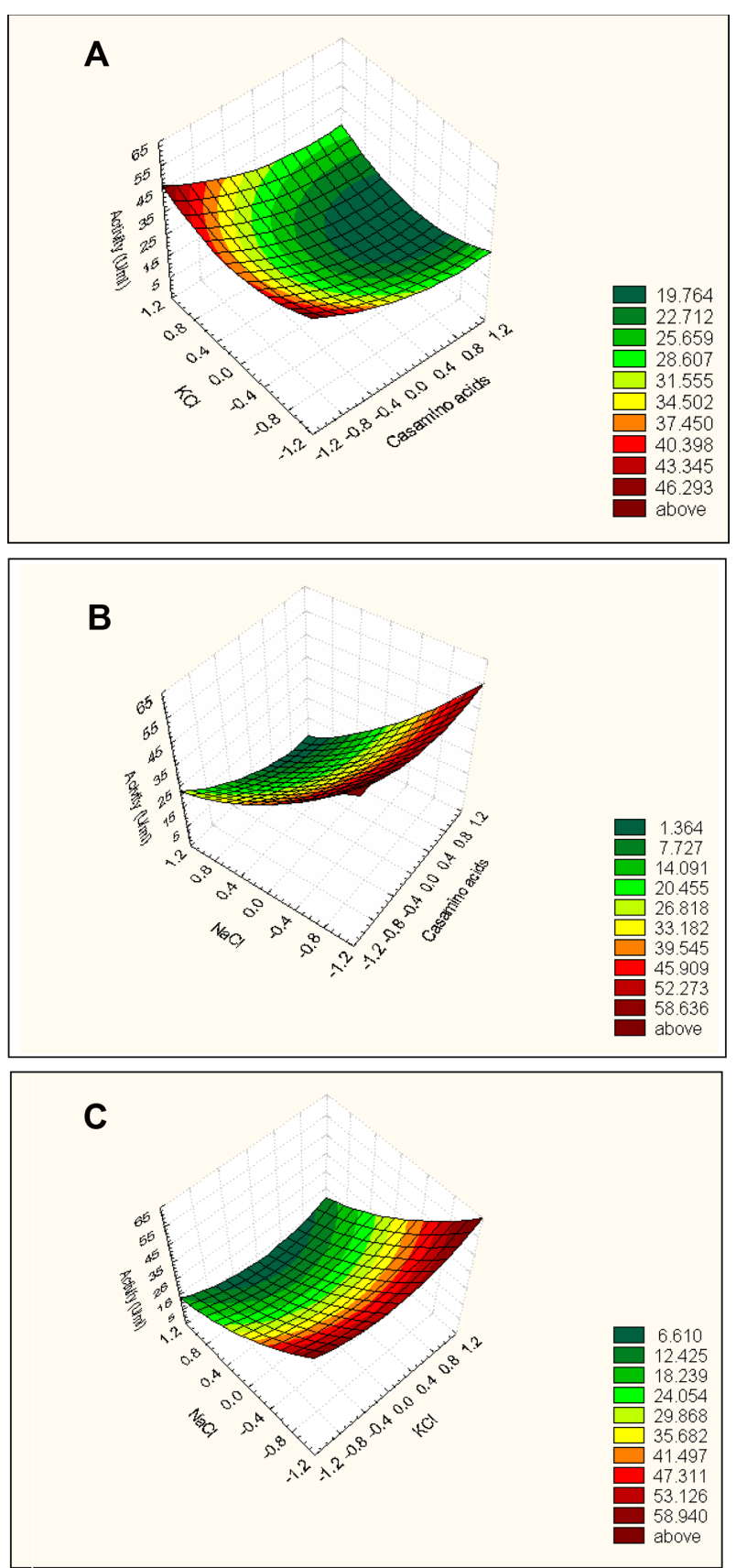

Fig. 3. Three-dimensional surface plots representing the effect of casamino acids, $\mathrm{KCl}$ and $\mathrm{NaCl}$ on the haloalkaline protease enzyme yield $\left(\mathrm{Uml}^{-1} \mathrm{~min}^{-1}\right)$ by $N$. hulunbeirensis strain WNHS14. (A) $\mathrm{KCl}$ versus casamino acids, (B) $\mathrm{NaCl}$ versus casamino acids, (C) $\mathrm{KCl}$ versus $\mathrm{NaCl}$. 
coefficient $R^{2}$. The closer the value of $R$ is to 1 , the better the correlation between the measured and the predicted values. In this experiment, the value of $R$ was 0.97 for the haloalkaline protease activity, indicating a high degree of correlation between the experimental and predicted values. Meanwhile, the value of the determination coefficient, $R^{2}=0.95$, for the haloalkaline protease activity, being a measure of fit for the model, indicated that only about $5 \%$ of the total variations were not explained by the enzyme activity.

The optimal levels of the three components, as obtained from the maximum point of the polynomial model, were then estimated using the Solver function of the Microsoft Excel tools and found to be casamino acids, $0.5 \% ; \mathrm{KCl}, 0.02 \% ; \mathrm{NaCl}, 15 \%$ with a predicted activity of $62.9 \mathrm{U} / \mathrm{ml}$. As such, the value of the enzyme activity in the optimized medium was more than 6 fold the value under basal conditions, thereby emphasizing the necessity and value of the optimization process.

To determine the accuracy of the quadratic polynomial model, a verification experiment was carried out under the predicted optimal conditions. As a result, the estimated haloalkaline protease activity was $58.2 \mathrm{U} / \mathrm{ml}$, while the predicted value from the polynomial model was $62.9 \mathrm{U} / \mathrm{ml}$. This high degree of accuracy of (92.53\%) was an evidence for the model validation under the following optimal conditions: $0.5 \%$ casamino acids, $0.02 \% \mathrm{KCl}$ and $15 \% \mathrm{NaCl}$ at $\mathrm{pH} 9$ adjusted with sterile $\mathrm{Na}_{2} \mathrm{CO}_{3}$.

Most microorganisms utilize organic and inorganic nitrogen sources to produce mainly amino acids, nucleic acids, proteins, and cell wall components. The availability of nitrogen sources in the media control the production of extracellular proteases. The synthesis of protease by microorganisms can be repressed by either an excess or a deficiency of nitrogen [28].

The organic nitrogen sources used in this study supported the proteolytic production from $N$. hulunbeirensis strain WNHS14, while the absence of organic nitrogen sources did not support it . The maximum effect on protease secretion $(36.2 \mathrm{U} / \mathrm{ml})$ was observed by using casamino acids as a nitrogen source. Thus, casamino acids, the best nitrogen source, was further investigated via response surface methodology to assess its optimum concentration for the protease production. Casamino acids has also been reported to be the best organic nitrogen for protease production in the haloalkaliphilic Bacillus sp. RGR-14 [33]. Nevertheless, protease production was repressed in the presence of high concentrations of casamino acids. The experimental results showed that a lower casamino acids concentration (0.5\%) supported a high protease production level from $N$. hulunbeirensis strain WNHS14. There are several reports on the repressive role of organic nitrogen sources in alkaline protease production in which the end products of nitrogen metabolism repress the synthesis of proteases $[5,6,10]$. The extremely halophiles are salt-loving organisms. They not only tolerate but require $\mathrm{NaCl}$ concentrations above 10 to $15 \%$ for survival, and optimal growth is often obtained above $20 \% \mathrm{NaCl}$ [24]. Halophiles have evolved to live within their environmental conditions, rather than to adapt ways to circumvent it. They had to evolve a system to deal with extreme osmotic stress. Halophiles respond to osmotic pressure elevation in different ways. Some halophiles, mostly halophilic bacteria and eukaryotes, prevent the entry of inorganic salts into the cell and synthesize small organic molecules (like ectoine), known as osmolytes, to balance the osmotic pressure. The aerobic halophilic archaea, though, survive by accumulation of $\mathrm{KCl}$, i.e., inorganic ions, in the cytoplasm to provide osmotic equilibrium [13, 29, 36]. Most halophilic enzymes are inactivated and denatured at concentrations below $1 \mathrm{M} \mathrm{NaCl}$ [2].

Solubility, stability and conformation of a protein can be significantly affected by salt concentrations which ultimately affect its ability to function. At environments with low salt concentration, halophilic proteins have a very low solubility [26, 36]. Therefore, the study of $\mathrm{NaCl}$ and $\mathrm{KCl}$ concentrations and their effect on the extracellular protease production by $N$. hulunbeirensis strain WNHS14, a halophilic archaeal strain, was studied. The optimum $\mathrm{NaCl}$ concentration for the proteolytic production from $N$. hulunbeirensis strain WNHS14 was found to be $15 \%$. These results could be compared with that of the haloalkaliphilic bacterium S-20-9 in which protease secretion was maximum at $15 \% \mathrm{NaCl}$ [18]. A much higher salt requirement (20\%) for a serine protease secretion was reported in another halophilic archaebacteria Halogeometricum sp. TSS101 and Halobacterium sp. Js1 [42, 43].

The statistical optimization method is widely used and has a growing acceptance in biotechnology. For our 
knowledge, this study constitutes the first report of the statistical optimization of medium components for the extracellular protease production from Natrialba sp. However, response surface methodology has been used to optimize the protease production by the haloarchaeon Haloferax lucentensis VKMM 007 and that produced by the haloarchaeon Halobacterium sp. SP1(1) [3, 27].

\section{Growth curve and protease production}

Culturing of $N$. hulunbeirensis strain WNHS14 was carried out under basal and optimized conditions while monitoring the growth and haloalkaline protease production. As shown in Fig. 3, the basal medium showed a typical growth pattern and recorded a relatively low enzyme activity with the maximum (10 U/ml) attained after 170 h. Enzyme activity was detected in this complex medium, containing casamino acids (0.75\%) and yeast extract (1\%), as $N$. hulunbeirensis cells entered the stationary growth. On the other hand, using the optimized medium, containing casamino acids $(0.5 \%)$, the growth rate of $N$. hulunbeirensis strain WNHS14 was significantly faster than that using the initial medium, reaching the stationary phase earlier $(81 \mathrm{~h})$ compared to the initial medium (120 h). Furthermore, under the optimized conditions, higher level of extracellular protease $(58.2 \mathrm{U} / \mathrm{ml})$ was produced at earlier stages of growth (early exponential phase). Protease production maximized after $57 \mathrm{~h}$ incubation, which is $27 \mathrm{~h}$ earlier compared with the proteolytic enzyme from the extremely halophilic archaeon Halogeometricum sp. TSS101 [42].

The growth and protease production by N. hulunbeirensis strain WNHS14 indicates that there is a distinct growth associated nature of protease production. High enzymatic production coincided with high growth rate of cells. On the contrary, the extracellular protease production by the haloarchaeon Natrialba magadii ATCC 43099 is stimulated when the cells are stressed to grow at a slow rate [6]. Moreover, the archaeon Natronococcus occultus NCIBM 2192 was found to produce an extracellular protease in the late exponential and stationary growth phases and during starvation. The protease production from Natronococcus occultus NCIBM 2192 is thought to be induced in response to high cell density which may be indicative of quorum sensing signaling [31].

\section{Purification of haloalkaline protease}

The steps that used for the haloalkaline protease purification from $N$. hulunbeirensis strain WNHS14 were showed in Table 2. It was indicated that during purification steps the total protease activity reduced to about $428.4 \mathrm{U}(\sim 23 \%)$, and also the total protein content reduced to $0.334 \mathrm{mg}(\sim 97 \%)$ in comparison with the initial reading. However, the specific activity at the end of the purification steps was found to be $1282.63 \mathrm{U} / \mathrm{mg}$ comparing to $144.04 \mathrm{U} / \mathrm{mg}$ at the culture filtrate. It was indicated that the protease enzyme at the end of the purification steps was purified to 8.9 fold. Fig. 4 illustrates the pattern of protein profile before and after the purification. By comparing both patterns, the results revealed that there was an obvious disappearance of different protein bands from the crude enzyme after purification using gel filtration.

\section{Haloalkaline protease characterization}

The studied protease enzyme works optimally at $75^{\circ} \mathrm{C}$ when was examined in presence of $2.5 \mathrm{M} \mathrm{NaCl}$ and $\mathrm{pH} 9$ and thus can be classified as a thermoactive protease. The enzyme possessed $100 \%$ stability after $60 \mathrm{~min}$ at $55^{\circ} \mathrm{C}$, but it was less stable at higher temperatures. Moreover, although the optimum temperature of the enzyme activity is $75^{\circ} \mathrm{C}$, it possessed only $28.47 \%$ stability after $1 \mathrm{~h}$ incubation at the same temperature. Rapid thermal inactivation of such enzymes might be related to the increased rate of activity at high temperatures as

Table 2. Purification table of haloalkaline protease enzyme produced by $\mathbf{N}$. hulunbeirensis strain WNHS14.

\begin{tabular}{lccccc}
\hline \multicolumn{1}{c}{ Purification step } & Total activity $(\mathrm{U})$ & Total protein $(\mathrm{mg})$ & Specific activity $(\mathrm{U} / \mathrm{mg})$ & Purification (fold) & Yield (\%) \\
\hline CFS $^{1}$ & 1862.4 & 12.93 & 144.04 & 1.00 & 100 \\
Conc. CFS $^{2}$ & 968.0 & 2.55 & 379.61 & 2.64 & 52 \\
Gel filtration colum & 428.4 & 0.334 & 1282.63 & 8.90 & 23 \\
\hline
\end{tabular}

1: cell free supernatant, 2: concentrated cell free supernatant.

*Hiprep16/60 sephacryl S-100 HR column. 


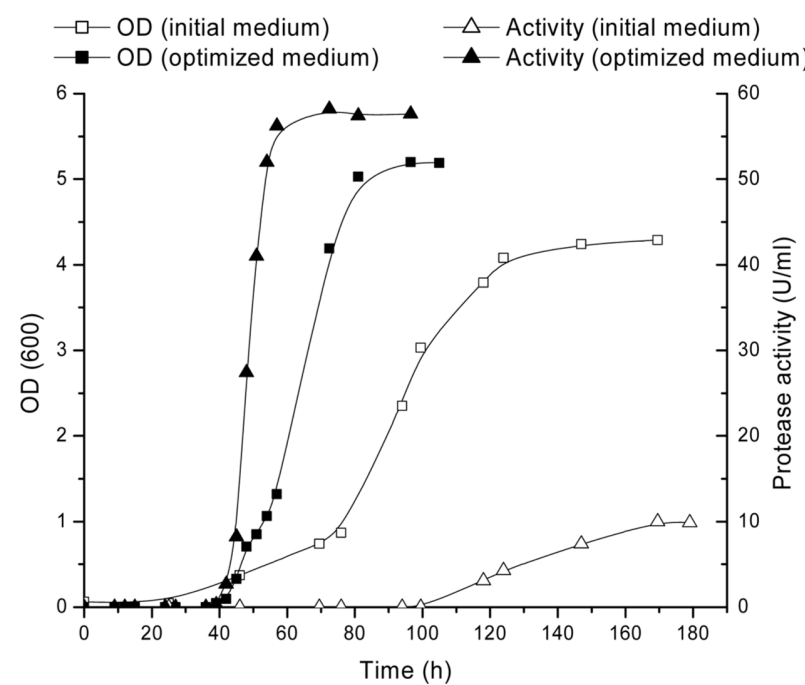

Fig. 4. Growth curve and haloakaline protease production by $N$. hulunbeirensis strain WNHS14 in initial and optimized media.

reported by Ghorbel et al. [11]. This is in agreement with haloalkaline protease isolated from Natrialba magadii [12] . Besides, the studied enzyme showed a broad $\mathrm{pH}$ range of activity with an optimum at $\mathrm{pH} 10$, declined slightly by increasing the $\mathrm{pH}$ and reached to about $91 \%$ relative activity at $\mathrm{pH} 11$. The enzyme was highly stable at $\mathrm{pH}$ ranging from 6 to 12 at room temperature throughout $1 \mathrm{~h}$. These results were highly similar with the literature results for the optimal $\mathrm{pH}$ [42] and for $\mathrm{pH}$ stability [12]. By testing salt dependence of enzyme, it was found that WNHS14 protease works optimally at $2 \mathrm{M}$ and retained $41 \%$ at $4.5 \mathrm{M}$ when assayed in $100 \mathrm{mM}$ carbonate buffer ( $\mathrm{pH} 10$ ). No activity was observed in absence of $\mathrm{NaCl}$ and complete irreversible loss of the enzyme activity even after elution of protein with non-saline buffer. These results revealed that the $N$. hulunbeirensis strain WNHS14 protease is a typical halophilic protease and similar to the haloalkaliphilic serine protease produced by Natrialba magadii [12] and by Natronococcus occultus NCBM 2192 [41]. In the contrary, the protease activity of the halophilic Bacillus sp. EMB9 was regained upon reintroducing $\mathrm{NaCl} / \mathrm{KCl}$ to the preparation soon after dialysis [40]. Following up the enzyme activity in presence of some surfactants showed that a slight decrease in the enzyme activity (3.25-11\%) with Tween-80, and 33.68-33.14\% with Triton X-100 at $1 \%$ concentrations (Table 3 ). A sharp decrease in the
Table 3. Effect of some surfactants, SDS, protease inhibitors and metal ions on activity of the partially purified $\boldsymbol{N}$. hulunbeirensis strain WNHS14 haloalkaline protease enzyme.

\begin{tabular}{lccc}
\hline \multirow{2}{*}{ Treatments } & \multicolumn{3}{c}{ Residual activity (\%) } \\
\cline { 2 - 4 } & $0.1 \%$ & $0.5 \%$ & $1 \%$ \\
\hline Control (no addition) & 100.0 & 100.0 & 100.0 \\
Tween-80 & 96.72 & 94.54 & 89.00 \\
Triton X-100 & 66.32 & 66.58 & 66.86 \\
SDS & 72.96 & 32.65 & 4.590 \\
\hline & $1 \mathrm{mM}$ & $5 \mathrm{mM}$ \\
\hline EDTA & 94.26 & 91.26 \\
$\mathrm{PMSF}$ & 21.00 & 0.00 \\
$\mathrm{Ca}{ }^{2+}$ & 97.96 & 95.41 \\
$\mathrm{Co}^{2+}$ & 99.44 & 59.18 \\
$\mathrm{Hg}^{2+}$ & 61.24 & 30.26 \\
$\mathrm{Mn}^{2+}$ & 96.87 & 89.88 \\
$\mathrm{~K}^{+}$ & 99.49 & 97.85 \\
$\mathrm{Cu}^{2+}$ & 90.24 & 79.59 \\
$\mathrm{Mg}^{2+}$ & 100.09 & 94.72 \\
$\mathrm{Fe}^{2+}$ & 93.64 & 80.33 \\
$\mathrm{Zn}^{2+}$ & 85.20 & 67.86 \\
\hline
\end{tabular}

proteolytic activity (95\%) was resulted by incubating the enzyme with SDS at 1\% concentration (Table 3). Similar results were obtained with Natrinema sp. strain J7 [39] and Halobiforma sp. strain BNMIITR [14] where SDS had a negative effect on the proteolytic activity. Moreover, as shown in Table 3 PMSF caused a complete inhibition of the partially purified enzyme activity at $5 \mathrm{mM}$, whereas $1 \mathrm{mM}$ caused $79 \%$ inactivation. PMSF is known to sulphonate the essential serine residue in the protease active site, causing a total loss of enzyme activity [22]. The enzyme complete inactivation by PMSF suggests that the protease produced by $N$. hulunbeirensis strain WNHS14 belongs to serine proteases family. This is not surprising as all of the extracellular proteases isolated so far from halophilic archaea are serine proteases. The limited inhibitory effect observed by EDTA (a specific inhibitor of metallo-type proteases) indicates that the metal ions are important but not essential for the WNHS14 proteolytic activity. Similar results were reported by Giménez et al. [12]. Additionally, all tested metal ions at low concentrations ( $1 \mathrm{mM})$ did not significantly affect the protease activity except for $\mathrm{Hg}^{2+}$ which decreased the proteolytic activity of the partially purified enzyme by $38.76 \%$ (Table 3 ). $\mathrm{Zn}^{2+}, \mathrm{Co}^{2+}$ and $\mathrm{Hg}^{2+}$ 


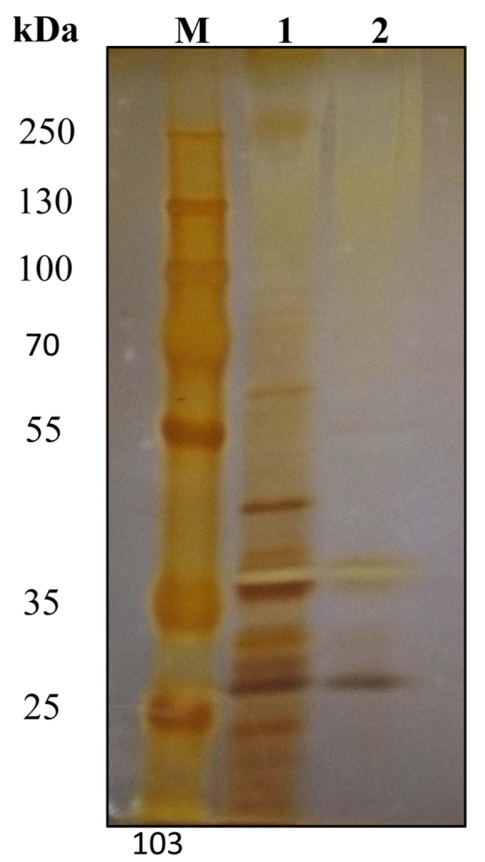

Fig. 5. SDS-PAGE of haloak 103 aline protease from $\mathbf{N}$. hulunbeirensis strain WNHS14. Lane M shows protein molecular weight protein marker, lane 1 shows the crude extract, and lane 2 shows the partially purified enzyme after elution from Hiprep16/60 sephacryl S-100 HR gel filtration column.

inhibited protease activity by $32.14,40.82$ and $69.74 \%$ at $5 \mathrm{mM}$, respectively (Table 3). This observations are in agreement with the halophilic serine protease isolate Natrialba asiatica $172 \mathrm{P} 1$ strain and Natronolimnobius innermongolicus WN18 strain [19]. However, the activity of this protease enzyme was enhanced in the presence of $\mathrm{Ca}^{2+}, \mathrm{Mn}^{2+}$ and $\mathrm{Mg}^{2+}$ ions [38]. This is in contrary of the present results at which these ions have no effect on the proteolytic activity. In conclusion this study has focused on the production, optimization, purification and characterization of the protease enzyme from a haloalkaliphilic archaeal species. Statistical optimization enhanced the production of protease by 6 -fold. To our knowledge, this is the first report of the production of extracellular proteolytic enzyme by $N$. hulunbeirensis and also the first report of the statistical optimization of medium components for the extracellular protease production from Natrialba sp. The promising properties of the newly haloalkaline serine protease from $N$. hulunbeirensis strain WNHS14 would underpin its efficient exploitation in several industries to cope with demands of worldwide enzyme markets.

\section{Acknowledgments}

The authors are extremely grateful to the City for Scientific Research and Technological Applications, Alexandria, Egypt for providing financial help and facilities to complete this work.

\section{Conflict of Interest}

The authors have no financial conflicts of interest to declare.

\section{References}

1. Abdel-Fattah YR, El-Enshasy HA, Soliman NA, El-Gendi H. 2009. Bioprocess development for production of alkaline protease by Bacillus pseudofirmus Mn6 through statistical experimental designs. J. Microbiol. Biotechnol. 19: 378-386.

2. Adams MWW, Kelly RM. 1995. Enzymes from microorganisms in extreme environments. Chem. Eng. News. 17: 32-42.

3. Akolkar A, Bharambe N, Trivedi S, Desai A. 2009. Statistical optimization of medium components for extracellular protease production by an extreme haloarchaeon, Halobacterium sp. SP1(1). Lett. Appl. Microbiol. 48: 77-83.

4. Castillo AM, Gutiérrez MC, Kamekura M, Ma Y, Cowan DA, Jones $\mathrm{BE}$, et al. 2006. Halovivax asiaticus gen. nov., sp. nov., a novel extremely halophilic archaeon isolated from Inner Mongolia, China. Int. Syst. Evol. Microbiol. 56: 765-770.

5. Chauhan B, Gupta R. 2004. Application of statistical experimental design for optimization of alkaline protease production from Bacillus sp. RGR-14. Process Biochem. 39: 2115-2122.

6. D'Alessandro CP, De Castro RE, Giménez Ml, Paggi RA. 2007. Effect of nutritional conditions on extracellular protease production by the haloalkaliphilic archaeon Natrialba magadii. Lett. Appl. Microbiol. 44: 637-642.

7. DasSarma S, DasSarma P. 2001. Halophiles, eLS. John Wiley and Sons Ltd, Chichester.

8. Desmarais D, Jablonski PE, Fedarko NS, Roberts MF. 1997. 2-Sulfotrehalose, a novel osmolyte in haloalkaliphilic archaea. J. Bacteriol. 179: 3146-3153.

9. Fan H, Xue Y, Ma Y, Ventosa A, Grant WD. 2004. Halorubrum tibetense sp. nov., a novel haloalkaliphilic archaeon from Lake Zabuye in Tibet, China. Int. Syst. Evol. Microbiol. 54: 1213-1216.

10. Ferrero MA, Castro GR, Abate CM, Baigorí MD, Siñeriz F. 1996. Thermostable alkaline proteases of Bacillus licheniformis MIR 29: isolation, production and characterization. Appl. Microbiol. Biotechnol. 45: 327-332.

11. Ghorbel B, Sellami-Kamoun A, Nasri M. 2003. Stability studies of protease from Bacillus cereus BG1. Enzyme Microb. Technol. 32: 513-518.

12. Gimenez MI, Studdert CA, Sánchez JJ, De Castro RE. 2000. Extracellular protease of Natrialba magadii: purification and biochemical characterization. Extremophiles 4: 181-188.

13. Gomes J, Steiner W. 2004. The biocatalytic potential of extremo- 
philes and extremozymes. Food Technol. Biotechnol. 42: 223-235.

14. Gupta M, Aggarwal S, Navani NK, Choudhury B. 2015. Isolation and characterization of a protease-producing novel haloalkaliphilic bacterium Halobiforma sp. strain BNMIITR from Sambhar lake in Rajasthan, India. Ann. Microbiol. 65: 677-686.

15. Gupta M, Sharma P, Dev K, Sourirajan A. 2016. Halophilic bacteria of Lunsu produce an array of industrially important enzymes with salt tolerant activity. Biochem. Res. Int. 2016: 1-10.

16. Hacěne $H$, Rafa $F$, Chebhouni $N$, Boutaiba $S$, Bhatnagar $T$, Baratti JC, et al. 2004. Biodiversity of prokaryotic microflora in El Golea Salt lake, Algerian Sahara. J. Arid Environ. 58: 273-284.

17. Hu L, Pan H, Xue Y, Ventosa A, Cowan DA, Jones BE, et al. 2008. Halorubrum luteum sp. nov., isolated from Lake Chagannor, Inner Mongolia, China. Int. Syst. Evol. Microbiol. 58: 1705-1708.

18. Joshi RH, Dodia MS, Singh SP. 2008. Production and optimization of a commercially viable alkaline protease from a haloalkaliphilic bacterium. Biotechnol. Bioprocess Eng. 13: 552-559.

19. Kamekura M, Seno Y. 1990. A halophilic extracellular protease from a halophilic archaebacterium strain 172 P1. Biochem. Cell Biol. 68: 352-359.

20. Kembhavi AA, Kulkarni A, Pant A. 1993. Salt-tolerant and thermostable alkaline protease from Bacillus subtilis NCIM No. 64. Appl. Biochem. Biotechnol. 38: 83-92.

21. Konig H, Stetter KO. 1989. Archaeobacteria, in Bergey's Manual of Systematic Bacteriology, pp. 2171-2253. Vol. 3, J.T. Staley MP, Bryant N Pfennig, and J.G. Holt, Editors. 1989, Williams and Wilkens, Baltimore.

22. Kumar CG. 2002. Purification and characterization of a thermostable alkaline protease from alkalophilic Bacillus pumilus. Lett. Appl. Microbiol. 34: 13-17.

23. Laemmli UK. 1970. Cleavage of structural proteins during the assembly of the head of bacteriophage T4. Nature 227: 680-685.

24. Lanyi JK. 1974. Salt-dependent properties of proteins from extremely halophilic bacteria. Bacteriol. Rev. 38: 272-290.

25. Lowry OH, Rosebrough NJ, Farr AL, Randall RJ. 1951. Protein measurement with the Folin phenol reagent. J. Biol. Chem. 193: 265-275.

26. Madern D, Ebel C, Zaccai G. 2000. Halophilic adaptation of enzymes. Extremophiles 4: 91-98.

27. Manikandan M, Kannan V, Velikonja BH, Pašić L. 2011. Optimization of growth medium for protease production by Haloferax Lucentensis VKMM 007 by response surface methodology. Braz. J. Microbiol. 42: 818-824.

28. Mortez E, Krogh TN, Vorum H, Görg A. 2001. Improved silver staining protocols for high sensitivity protein identification using matrix-assisted laser desorption/ionization-time of flight analysis. Proteomics 1: 1359-1363.

29. Oren A. 2007. Biodiversity in highly saline environments, in: Gerday, C., Glansdorff, N. (eds.), pp 223-231. Physiology and Biochemistry of Extremophiles. ASM Press, Washington.

30. Oren A. 2002. Diversity of halophilic microorganisms: environments, phylogeny, physiology, and applications. J. Ind. Microbiol. Biotechnol. 28: 56-63.
31. Paggi RA, Martone CB, Fuqua C, De Castro RE. 2003. Detection of quorum sensing signals in the haloalkaliphilic archaeon Natronococcus occultus. FEMS Microbiol. Lett. 221: 49-52.

32. Palsaniya P, Mishra R, Beejawat N, Sethi S, Gupta BL. 2012. Optimization of alkaline protease production from bacteria isolated from soil. J. Microbiol. Biotechnol. Res. 2: 858-865.

33. Patel R, Dodia M, Singh SP. 2005. Extracellular alkaline protease from a newly isolated haloalkaliphilic Bacillus sp., Production and optimization. Process Biochem . 40: 3569-3575.

34. Patel S, Saraf M. 2015. Perspectives and application of halophilic enzymes. pp 403-419. In Maheshwari, D.K., Saraf, M. (Eds.), Halophiles: Biodiversity and Sustainable Exploitation. Springer International Publishing, Cham.

35. Rahman RNZA, Geok LP, Basri M, Salleh AB. 2005. Physical factors affecting the production of organic solvent-tolerant protease by Pseudomonas aeruginosa strain K. Bioresour. Technol. 96: 429-436.

36. Sánchez-Porro C, Mellado E, Bertoldo C, Antranikian G, Ventosa A. 2003. Screening and characterization of the protease CP1 produced by the moderately halophilic bacterium Pseudoalteromonas sp. strain CP76. Extremophiles 7: 221-228.

37. Schiralid C, Giuliano M, De Rosa M. 2002. Perspectives on biotechnological applications of archaea. Archaea 1: 75-86.

38. Selim S, Hagagy N, Aziz MA, El-Meleigy ES, Pessione E. 2014. Thermostable alkaline halophilic-protease production by Natronolimnobius innermongolicus WN18. Nat. Prod. Res. 28 : 1476-1479.

39. Shi W, Tang X-F, Huang Y, Gan F, Tang B, Shen P. 2006. An extracellular halophilic protease SptA from a halophilic archaeon Natrinema sp. J7: Gene cloning, expression and characterization. Extremophiles 10: 599-606.

40. Sinha R, Khare SK. 2013. Characterization of detergent compatible protease of a halophilic Bacillus sp. EMB9: Differential role of metal ions in stability and activity. Bioresour. Technol. 145: 357-361.

41. Studdert CA, Herrera Seitz MK, Plasencia Gil MI, Sanchez JJ, de Castro RE. 2001. Purification and biochemical characterization of the haloalkaliphilic archaeon Natronococcus occultus extracellular serine protease. J. Basic Microbiol. 41: 375-383.

42. Vidyasagar M, Prakash SB, Sreeramulu K. 2006. Optimization of culture conditions for the production of haloalkaliphilic thermostable protease from an extremely halophilic archaeon Halogeometricum sp. TSS101. Lett. Appl. Microbiol. 43: 385-391.

43. VijayAnand S, Hemapriya J, Selvin J, Kiran S. 2010. Production and optimization of haloalkaliphilic protease by an extremophile-Halobacterium sp. Js1, isolated from thalassohaline environment. Glob. J. Biotechnol. Biochem. 5: 44-49.

44. Woese CR, Fox GE. 1977. Phylogenetic structure of the prokaryotic domain: The primary kingdoms. Proc. Natl. Acad. Sci. 74: 50885090.

45. Xu Y, Zhou P, Tian X. 1999. Characterization of two novel haloalkaliphilic archaea Natronorubrurn bangense gen. nov., sp. nov. and Natronorubrurn tibetense gen. nov., sp. nov. Int. Syst. Evol. Bacteriol. 49: 261-266. 